\title{
LANDSLIDE RECLAMATION IN ŠÁRKA VALLEY
}

\author{
MARTIN VANÍČEK
}

\author{
Geosyntetika s.r.o., Nikoly Tesly 3, Prague 6, Czech Republic \\ correspondence: mvanicek@geosyntetika.cz
}

\begin{abstract}
Housing development in Šárka's valley is situated in former brickworks - borrow pit for brick-clay. On its north side the borrow pit cutting is up to $8 \mathrm{~m}$ high with main road on top. This slope was suffering from progressive landslide mainly due to weathering and surface erosion. The reclamation works proposed and afterwards executed consisted of stabilizing the slope by combination of soil nailing and connecting reinforced slope with surcharge bench at its toe. The final reinforced soil structure nicely merged into the surrounding environment.
\end{abstract}

KEYWORDS: Landslide reclamation, Muralex stone facing system, reinforced soil structure.

\section{INTRODUCTION}

Main task of this project was to design and later to execute the reclamation of landslide below the edge of Horoměřická street. The slope is part of housing development project Top Residence Šárecké údolí. This development project is situated in the area of former brickworks. The slope that has been progressively collapsing was up to $8 \mathrm{~m}$ height with the slope as steep as 1:1. The progressive collapse was initiated by climatic degradation of brick clay and surface erosion on the steep slope.

\section{Geotechnichl Conditions}

In the area of the whole development project the geotechnical investigation has been performed. Several boreholes and trial pits have been used to determine the geological structure of the area. As is typical for such projects the soil properties have been suggested from the index tests performed on few disturbed samples taken and from the description of soils encountered during exploratory works. In the area of landslide additional GI was undertaken, however again without determination of shear strength of encountered soils.

Based on the above information simple geotechnical model was determined. On site bedrock from weathered clayey shales was found, categorised as R5 based on Czech code of practise. The depth to weathered bedrock was indicated between 1 and $4 \mathrm{~m}$ with respect to the borehole location within the slope. The shales were overlaid by clayey sandy silt (brick clay), based on classification CS - Sandy Clay firm to stiff consistency. Near the surface a layer with organic content was present. Shear strength properties of soils have been selected with respect to Eurocode 7 guidelines as very cautious value from tabled values of soil properties in discontinued Czech code of practise ČSN 731001.

For the construction of new earth structure body, it was in the design assumed to use local soils from base- ment excavation for houses. Also for recompacted soils from excavations the tests for determination of shear strength haven't been performed, therefore their characteristic properties have been selected as very cautious values from tabled soil properties in ČSN 752410, Czech code of practise for earth dams.

Selected characteristic soil properties for reinforced soil structures are presented in table 1 below.

Based on above mentioned investigation typical cross section through land slide has been created and assumed location of slip surface together with individual soil layers has been indicated in Fig. 1 .

Ground water level has been found under the slope relatively shallow, about $1 \mathrm{~m}$ below ground level. In the borehole $5.5 \mathrm{~m}$ deep from top of the slope, ground water hasn't been found. This indicates that ground water level does not copy the ground surface and is rather naturally gradual.

\section{Proposed SOLUTion}

In accordance with proposed development project the bottom line of reclamation is defined by edge of unbound cycleway. In order to guarantee required stability of the reclaimed slope, it's inclination is proposed at 1:1.75 - 1:2.00 with reinforcement in $1 \mathrm{~m}$ spaced layers. Due to limited space, the slope has to be ended by retaining wall with max. height of $1.6 \mathrm{~m}$. Based on main architect requirement the retaining wall should have gabion facing.

At the top edge of the slope, it was not possible to do any large excavations, as there is situated highly trafficked street Horoměřická. In order to cut through the potential slip surface, driven soil nails in $1 \mathrm{~m}$ vertical and $1.5 \mathrm{~m}$ horizontal spacing inclined by $60^{\circ}$ from horizontal have been proposed. These soil nails from $50 \times 6.3 \mathrm{~mm}$ steel pipe with $1.5 \mathrm{~m}$ length have been located into the steps in existing slope excavations created for better connection with new slope.

Stability of the new slope is maintained by reinforcing geogrids Fortrac® MPT, with vertical spacing of $0.5 \mathrm{~m}$ or $1 \mathrm{~m}$ depending on the position in the slope. 


\begin{tabular}{lcccc}
\hline $\begin{array}{c}\text { Soil layer } \backslash \\
\text { properties }\end{array}$ & $\begin{array}{c}\text { Effective angle of } \\
\text { internal friction } \\
\varphi^{\prime}\end{array}$ & $\begin{array}{c}\text { Effective } \\
\text { cohesion } \\
\mathrm{c}^{\prime}\end{array}$ & $\begin{array}{c}\text { Weight density } \\
\text { of soil } \\
\gamma\end{array}$ & $\begin{array}{c}\text { Weight density of } \\
\text { saturated soil } \\
\gamma_{\text {sat }}\end{array}$ \\
\cline { 2 - 5 } & ${ }^{\mathrm{kN} / \mathrm{m}^{2}}$ & $\mathrm{kN} / \mathrm{m}^{3}$ & $\mathrm{kN} / \mathrm{m}^{3}$ \\
\hline Brick clay & 23,00 & 8,00 & 19,50 & 21,00 \\
Weathered shale & 30,00 & 20,00 & 20,50 & 21,50 \\
New backfill & 25,00 & 5,00 & 20,00 & 20,50 \\
\hline
\end{tabular}

TABLE 1. Characteristic soil properties assumed.

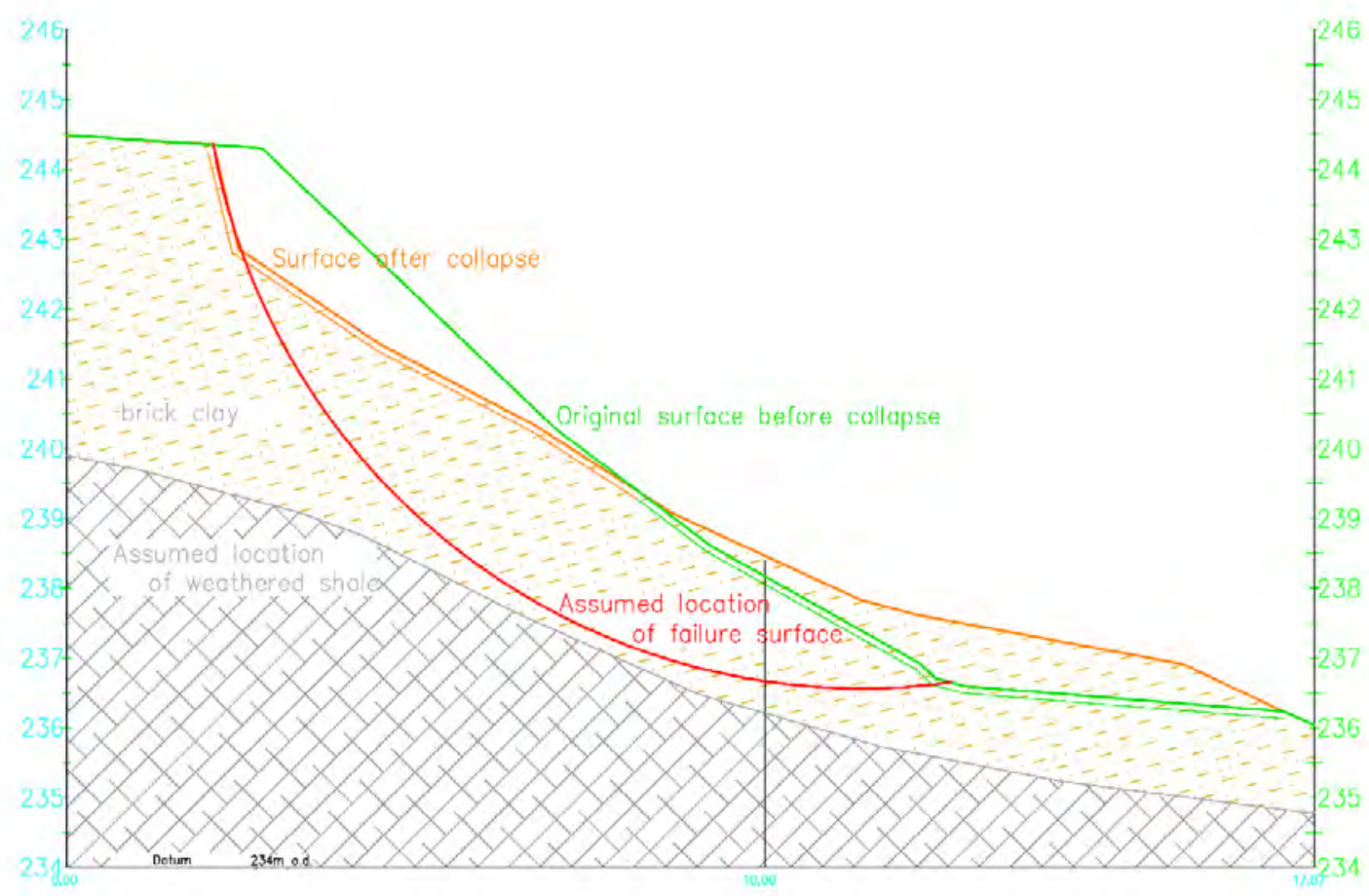

FiguRE 1. Cross section of collapsed slope with indicated assumed geotechnical layers and slipped surface.

The length of geogrids is given between slope face and steps in existing ground, where they are connected to the soil nails by nail heads. The base retaining wall with vertical gabion type facing was designed as MURALEX® Stone system. Above the base retaining wall drainage channel was created to drain the surface water from the slope.

On eastern side the reclamation is framed by the underpass under the Horoměřická street with brick cladding of the steep slope above the underpass portal (see visualization on Fig. 2). Slope above portal wing wall is again retained by max. $3 \mathrm{~m}$ high retaining wall with MURALEX® Stone system. The western side of slope reclamation is framed by newly planned staircase. The level difference between existing slope and reclaimed slope towards the planned staircase is proposed as reinforced steep slope (4:1) with MURALEX® Green system, which provides vegetated surface.

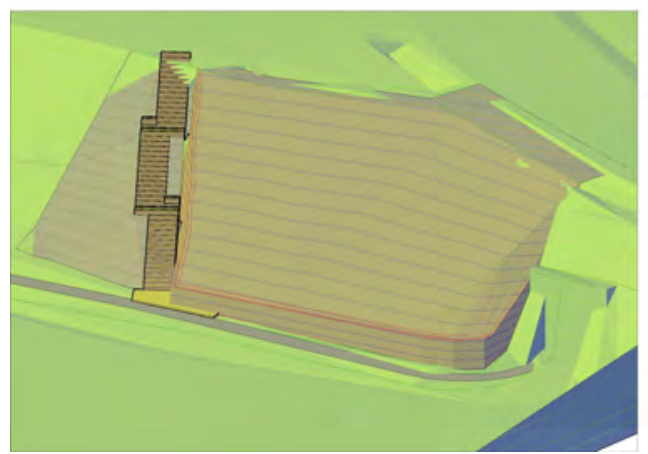

FigURE 2. Visualization of reclaimed slope integration into the existing terrain

Design solution has been developed in accordance to Eurocode 7, namely based on experience. Typical cross section through reclaimed slope is shown in Fig. 3. 


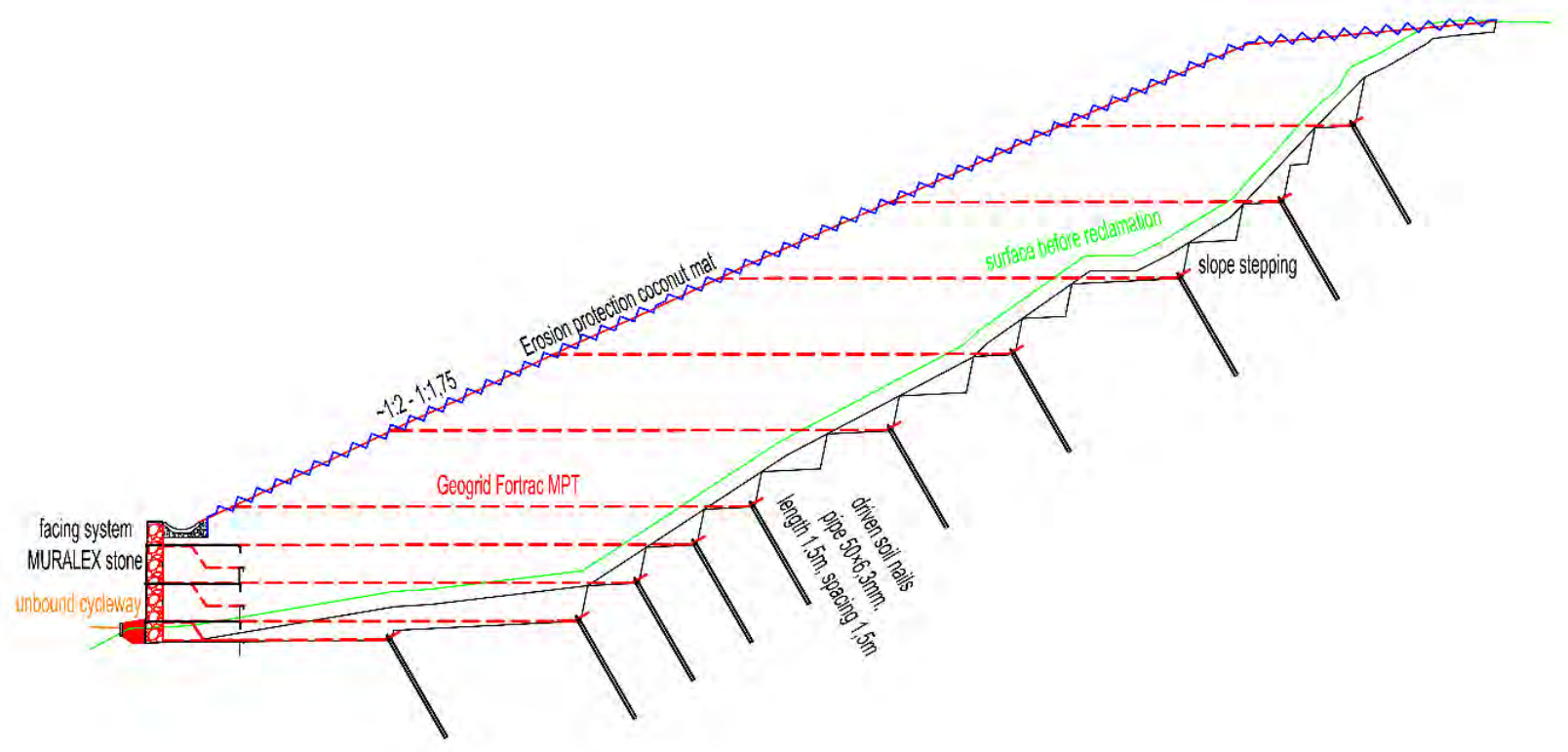

FiguRE 3. Typical cross section through the reclaimed collapsed slope

\section{Reclamation execution}

Next to design solution the developer and main contractor of the whole housing development asked us to also take care about the execution of reclamation works.

The actual conditions have proven the design assumptions, except the shallower depth of weathered shales close to slope base, where we have some problems with nails driving. This issue was easily solved by shortening of the nails, which does not influence the overall stability. In the upper part the soil nails have been driven well behind the assumed slip surface, along which the slope most probably earlier collapsed.

Another emerged issue in lack of locally available soil was again easily solved by importing of the suitable soil. This imported soil was tested in lab for shear strength and compaction efficiency by Proctor standard test including the optimal moisture content for compaction.

Reclamation was executed according to plan also due to highly permitting weather.

wall from reinforced soil was build using wrap around technique, when individual layers have been compacted against mobile formwork (see Fig. 4). At each geogrid layer, anchoring elements have been installed for future connection of MURALEX® facing elements. At these layers were also installed driven

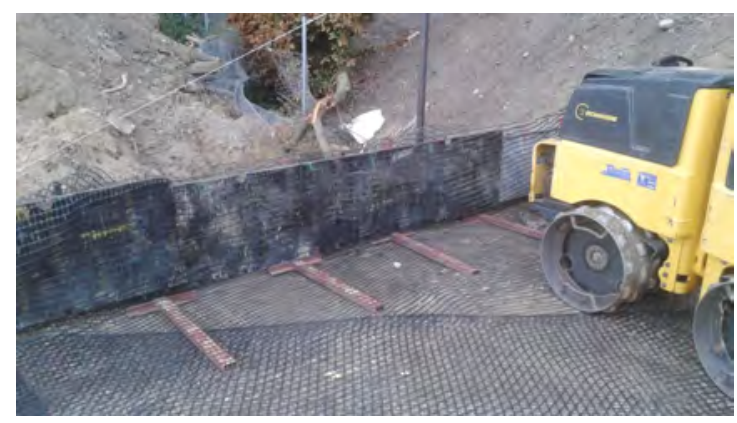

FigURE 4. Formwork for proper compaction of reinforced soil structure with wrap-around facing in the facing area.

soil nails and connected to the geogrids strips with help of nail heads (see Fig. 5). Above the base retaining wall new slope was built with the inclination in between 1:1.75 and 1:2.00 based on space availability. The soil was compacted by plate and ditch roller and compaction quality was tested by light dynamic plate test.

Once the slope was built and ramp for machinery access removed, attached front facing MURALEX® system was installed (see Fig. 6). In locations with vertical facing, the system was filled with stones $63 / 125 \mathrm{~mm}$ and in locations with 4:1 slope facing, sieved organic soil filling was used. Lastly the slope 


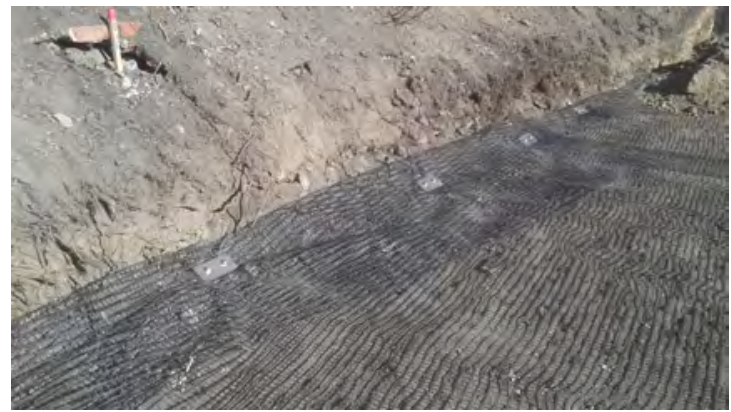

FiguRE 5. Connection of reinforcing geogrids Fortrac ${ }^{\circledR}$ MPT and driven soil nails

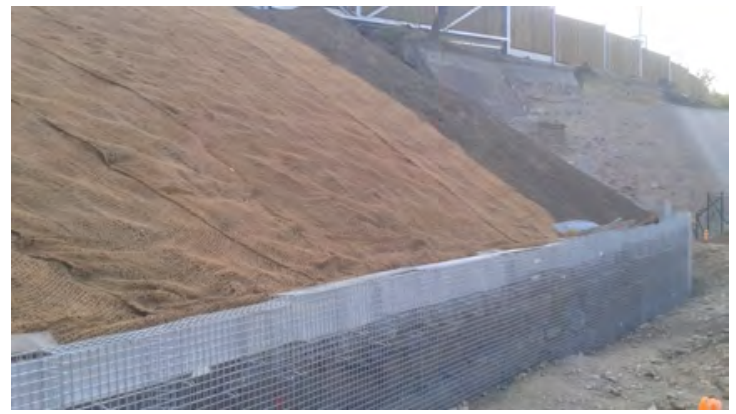

Figure 6. Attached front facing system MURALEX® before $63 / 125 \mathrm{~mm}$ stone filling

was covered with topsoil and temporary erosion protection mesh from coconut fibres. Afterwards the whole slope surface was covered by grass seeds. Already

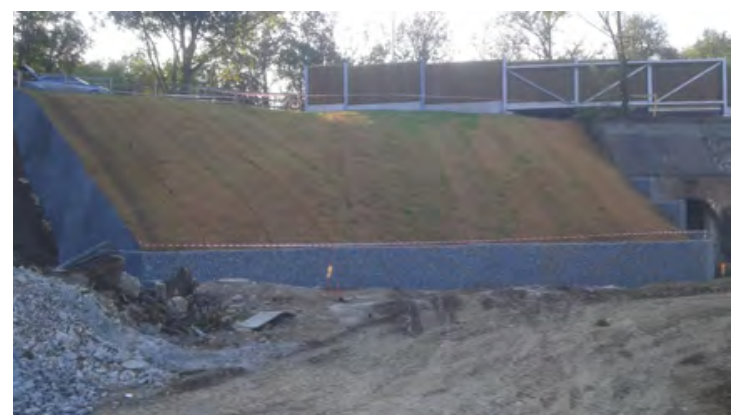

Figure 7. Overall view on the finished reclaimed slope, where grassing can be seen

after couple of days the slope started to be nicely grassed (see Fig. 7).

\section{SUMMARY}

Finally it can be concluded that even at confined conditions it is possible to reclaim collapsed slope by appropriate combination of soil reinforcement techniques - soil nailing and soil reinforcement by Fortrac® MPT geogrids. The final visual perception nicely implemented the reclaimed slope into high standard housing development. The system of attached front facing MURALEX® ${ }^{\circledR}$ creates aesthetic element, which can be during the lifetime of reinforced soil structure repaired or modified from whatever reasons (e.g. accident, change of aesthetic feeling, ...) without compromising the main retaining soil structure. 